\title{
Land Use Change and Its Determinant Factors in Northern Laos: Spatial and Socio-economic Analysis
}

\author{
SouthavilayBoundeth ${ }^{1}$, Teruaki Nanseki ${ }^{2}$, ShigeyoshiTakeuchi ${ }^{2}, \&$ Tetsuo SATHO ${ }^{3}$ \\ ${ }^{1}$ Graduate School of Bioresource and Bioenvironmental Science, Laboratory of Agricultural and Farm \\ Management, Department of Agricultural and Resources Economics, Kyushu University, 6-10-1 Hakozaki, \\ Higashi-ku, Fukuoka, Japan \\ ${ }^{2}$ Faculty of Agriculture, Kyushu University, 6-10-1 Hakozaki, Higashi-ku, Fukuoka, Japan \\ ${ }^{3}$ Department of Geography, Komazawa University, Tokyo, Japan \\ Correspondence: TeruakiNanseki, Faculty of Agriculture, Kyushu University, 6-10-1 Hakozaki, Higashi-ku, \\ Fukuoka, Japan. Tel: 81-926-422-970, ext. 2972. E-mail: nanseki@agr.kyushu-u.ac.jp
}

Received: September 6, 2012 Accepted: September 24, 2012 Online Published: November 15, 2012

doi:10.5539/jas.v4n12p190 URL: http://dx.doi.org/10.5539/jas.v4n12p190

\begin{abstract}
Changes in land use areoften associated with policy implementation and socio-economic factors. The objective of this study was to interpret the patterns of land use and changes in land cover with a watershed area, especially focusing on the detection of change of agricultural land. The socio-economic factors contributing to land change was also analyzed. This study adopted both spatial and socio-economic analysis with remote sensing and logistic regression model. Land use maps of the study area for the years 2001, 2004, 2007 and 2010 were interpreted from Landsat 5 TM and prepared with eight classes of land use/land cover types. This study revealed that the land use/land cover in the study area had dynamically changed with socio-economic factors in each period. Particularly, $70 \%$ of forest covers had significantly decreased in contrast to the increase of other land use types such as secondary forest/mixed or shrubland and agricultural land. The logistic regression model provided results of socio-economic factors that influenced land use changein each period.
\end{abstract}

Keywords: agriculture, GIS and remote sensing, land use/land cover, socio-economic factor

\section{Introduction}

The policy of Lao government to promote commercial agriculture has brough rapid land use and land cover changes. It means thatfarmers are quick in converting their land (swidden and fallow field) to cultivate cash crops such as maize, banana, watermelons and rubber plantation. As a consequence, agricultural and forest conversation conflicts are becoming more severe andwidespreadthroughout the country. Several authors have accounted that. For example, the case studies on land use change in Southeast Asia indicate that mounting political and economic pressure on commercially valuable natural resources and upland agricultural system is one of the leading causes of forest degradation (Fox \& Vogler, 2005; Kummer \& Turner, 2007).

On the other hand, the growing population and theincreasing socio-economic necessities havecreated pressures on land use and land covers. This resulted in the expansion of agricultural land areas, which become the main driving force to land use and land cover changes. Hence, to better understand the causes and processes of land use and land cover changes, it is necessary to examine the not only the physical patterns of change but also the factors influence farmers' relationship with their farmlands.

Therefore, this study adopted both spatial and socio-economic analysis by integration GIS-remote sensing and socio-economic data. Remote sensing isa powerful tool in deriving accurate and timely information on the spatial distribution of land use/land cover changes over large areas (Rogana \& Chen, 2004; Campbell, 2007). Remote sensing techniques offer benefits in the field of analysis on land use and land cover mapping and its change (Mahmoodzadeh, 2007). Meanwhile, GIS provides a flexible environment for collecting, storing, displaying and analyzing digital data necessary for change detection (Demers, 2005). The change detection process recognizes land use and land cover change on digital images, with respect to the feature of interest between two or more years. In this study, we analyzed four sets of land use maps generated from Landsat 5TM satellite images covering years 2001/2004; 2004/2007; 2007/2010 and 2001/2010. 
However, this study aims not only to assess changing land use patterns, but also examine the socio-economic factors that influence farmers or stakeholders' decision on land utilization and land management. The findings of this study will be useful in making policy decision related to farm management and land use planning in the study area. Therefore, the objectives of this study aimed to analyze dynamics of land use and land cover changesfor the years 2001, 2004, 2007 and 2010, and to determine socio-economic factors that affected land use changes.

\section{Study Area}

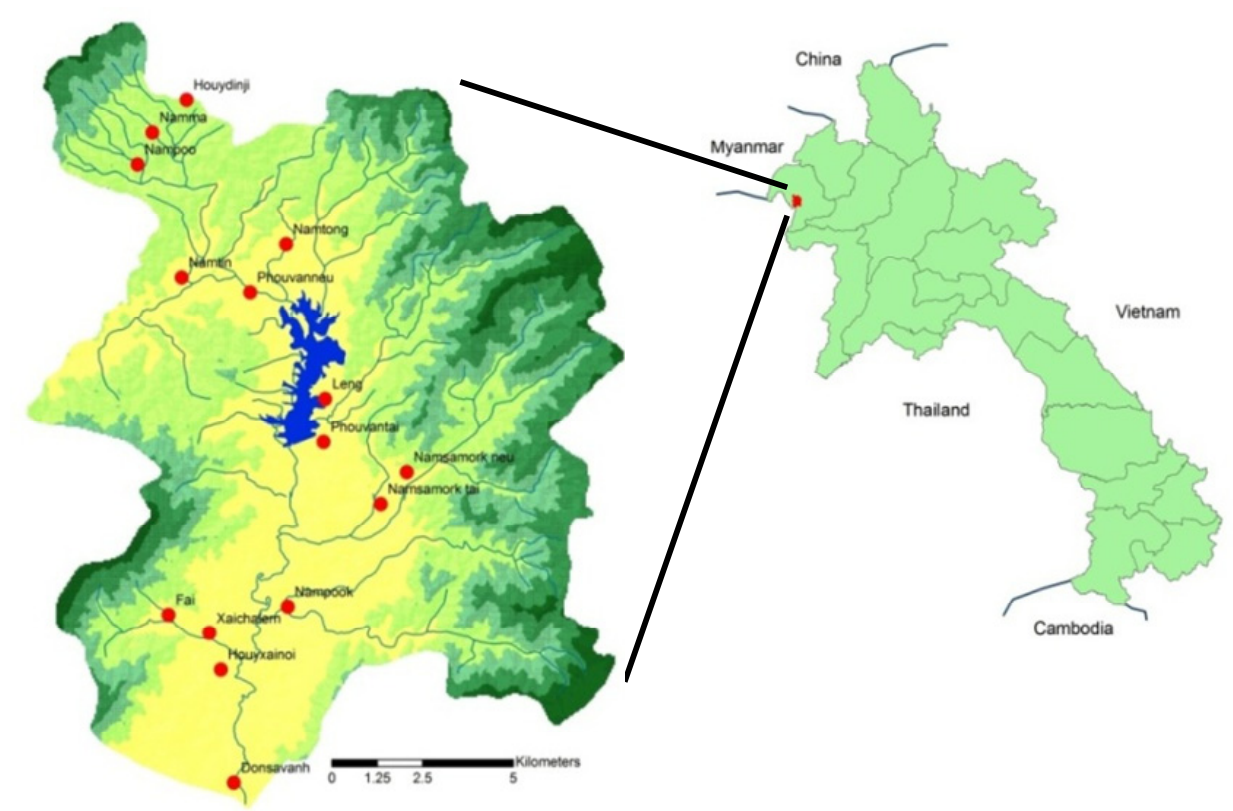

Figure1. Study Site (It is converted by the scenes of Landsat 5 TM, path 130/row 46)

Figure 1 shows the study site that is located in HouayXai District, Bokeo Province, Laos and which is demarcated with a watershed boundary, centering on $20^{\circ} 18^{\prime} 04.49^{\prime \prime} \mathrm{N} / 100^{\circ} 35^{\prime} 51.75^{\prime \prime} \mathrm{E}$. The watershed area is called Nam Tin watershed. It has a total land area of 22,000 ha and included by 16 villages with a population of 13,550 people in 2011. Most of the people living in the areaare engaged in agriculture.

This area was selected as the study site because it clearly shows the effects of agricultural development policies on the change of land use and land covers for the last 10 years. In 2001, an irrigation dam was constructed for purpose of reducing the problem of shifting cultivation, and to promote lowland rice and cash crop production. Thereafter, a policy called "promotion of agricultural commercial production" has been introduced in the area since 2006. As the result of this policy, the land use and land covers of the Nam Tin watershed have dramatically changed over the past years.

\section{Materials}

Land use maps were generated from Landsat 5TM (Path 130/Row 46) covering the periods of 2001, 2004, 2007 and 2010 was used to prepare land use maps and to monitor the land use/land cover changes. For the change detection, two time series images of Lands at 5TM 2001/2004; 2004/2007; 2007/2010 and 2001/2010 were compared. These four time series images of satellite were provided by a commercial data provider (GISTDA, Thailand). The radiometric correction and removal of systematic errors were completed by the data provider. The raw images were also geometrically corrected by the provider. The pixel resolution is $25 \times 25$ meters. The dates of image acquisition were chosen to be as closely as possible in the same crop season. All visible and infared bands were utilized in the analysis, except the thermal infrared (band 6). In order to get higher accuracy of image interpretation, ground truth was collected with GPS at scatteredpoints throughout the study area. Other materials used are raster and vector data of Digital Elevation Model (DEM), slope, contour line, watershed boundary, river network, road network, village points and so on. Pixel dimensions of DEM and slope map are 50 x 50 meters. 
In order to understand the situation of land use changes and its determinants, both socio-economic and spatial data survey are needed to conduct. Personal interview of 75 farmers were conducted and also plotted using GPS to better understand the socio-economic determinants of land use change. Structured questionnaires were used to extract household information and agricultural activities from the respondents. Most specially, farmers were asked about their activities related to rubber plantation, paddy field, maize farmland,including the pattern of land use change over the past years. Othelocal stakeholders such as rubber plantation owner, private sector and district administrative offices such as District Planning and Investment Office, District Agriculture and Forestry Office were also interviewed.

Table 1. Classification of GPS points

\begin{tabular}{|c|c|c|c|}
\hline $\begin{array}{l}\text { Classified Land use } \\
\text { of GPS points }\end{array}$ & $\begin{array}{l}\text { ID of } \\
\text { Land }\end{array}$ & $\begin{array}{l}\text { Numbers of GPS } \\
\text { record points }\end{array}$ & Observations \\
\hline Paddy field & 1 & $\begin{array}{c}15 \\
(20 \%)\end{array}$ & $\begin{array}{l}\text { Located on flatland and not so much changed for } \\
\text { the last } 10 \text { years }\end{array}$ \\
\hline Rubber plantation & 2 & $\begin{array}{c}14 \\
(19 \%)\end{array}$ & $\begin{array}{l}\text { The area was converted from fallow forest or } \\
\text { upland rice field and can be seen throughout } \\
\text { study area }\end{array}$ \\
\hline Maize farmland & 3 & $\begin{array}{c}11 \\
(15 \%)\end{array}$ & $\begin{array}{l}\text { Some of maize areas have been cultivated for } \\
\text { more than } 10 \text { years but some areas were newly } \\
\text { converted from upland rice field in recent years }\end{array}$ \\
\hline Water melon field & 4 & $\begin{array}{c}4 \\
(5 \%)\end{array}$ & $\begin{array}{l}\text { This area was converted from paddy field, to be } \\
\text { found around the upper area within watershed }\end{array}$ \\
\hline Banana field & 5 & $\begin{array}{c}5 \\
(7 \%)\end{array}$ & $\begin{array}{l}\text { Some fields were converted from maize field and } \\
\text { shrub land that can be seen around downstream } \\
\text { within watershed }\end{array}$ \\
\hline Garden/shrub & 6 & $\begin{array}{c}10 \\
(13 \%)\end{array}$ & $\begin{array}{l}\text { This area is mixed with shrub and fruit tree, } \\
\text { usually located near the paddy field, and } \\
\text { commune villages }\end{array}$ \\
\hline Upland rice field & 7 & $\begin{array}{c}10 \\
(13 \%)\end{array}$ & $\begin{array}{l}\text { This area was found throughout the study area } \\
\text { and located along the foothill and closed to } \\
\text { villages }\end{array}$ \\
\hline $\begin{array}{l}\text { Wetland/irrigated } \\
\text { areas }\end{array}$ & 8 & $\begin{array}{c}6 \\
(7 \%)\end{array}$ & $\begin{array}{l}\text { Land close to reservoir and along the irrigation } \\
\text { canals }\end{array}$ \\
\hline Total & & 75 (100\%) & \\
\hline
\end{tabular}

Table 1 shows the 75 GPS points belong to 75 farmers who were interviewed during the field survey. Both local authorities and village headmen participated in the marking of GPS piont in order to the location of the farms and its corresponding owners.

\section{Methods}

\subsection{Image Classification}

The data base of raster and vector files of this study site were subset and combined by using ArcGIS software version 9.3. Meanwhile, ERDAS Imagine Software version 9.2 was also used to elaborate preprocessing and classification of the satellite images. All bands except Band6 were consulted for identifying the area of interests (AOI). Image enhancement was applied through histogram manipulation. The classified images were generated by supervised classification method with signature editor of AOI files. The supervised classification was adopted maximum likelihood approach to classify the image witheight classes of land use and land cover. After preparation of four land use maps, two sets of land use maps covering years of 2001/2004; 2004/2007; 2007/2010 and 2001/2010 were compared for change detection. 
Table 2. Description of land use and land cover class

\begin{tabular}{|c|c|c|}
\hline No. & Land cover classes & Description \\
\hline 1 & Dense forest & $\begin{array}{l}\text { Land cover dominated by trees with crown cover density over } 20 \% \text {. } \\
\text { Trees have DBH (Diameter at Breast, Height) measurement of more } \\
\text { than } 10 \mathrm{~cm} \text { and the heights are more than } 10 \mathrm{~m} \text { tall. These land covers } \\
\text { are usually designed as protected forest or conservation forest, which } \\
\text { found on the steep terrain in high mountains. }\end{array}$ \\
\hline 2 & $\begin{array}{l}\text { Secondary forest/ } \\
\text { Mixed and shrub }\end{array}$ & $\begin{array}{l}\text { No presence of large trees but mostly dominated by bamboo or shrub } \\
\text { land. Trees have DBH of less than } 10 \mathrm{~cm} \text { and are shorter than } 10 \mathrm{~m} \text {. } \\
\text { Most of this area is old swidden fallow forests. This category is found } \\
\text { throughout the watershed area and is often changed to active } \\
\text { swiddenfields. }\end{array}$ \\
\hline 3 & $\begin{array}{l}\text { Lowland agricultural } \\
\text { land }\end{array}$ & $\begin{array}{l}\text { All agricultural lands with gentle slope equal to or less than } 8 \% \text {. This } \\
\text { category mainly includes lowland paddy field, maize, cash crop, pasture } \\
\text { for cattle grazing and other clear lands. }\end{array}$ \\
\hline 4 & $\begin{array}{l}\text { Upland agricultural } \\
\text { land }\end{array}$ & $\begin{array}{l}\text { All agricultural lands with slope steeper than } 8 \% \text {. There are mainly } \\
\text { upland rice field, fallow or other land newly cleared for agricultural } \\
\text { purpose such as maize cultivation or rubber plantations. }\end{array}$ \\
\hline 5 & Rubber plantation & $\begin{array}{l}\text { This category is old swidden fallow forest and found throughout the } \\
\text { watershed area. }\end{array}$ \\
\hline 6 & $\begin{array}{l}\text { Wetland/Irrigated } \\
\text { paddy }\end{array}$ & This category includes irrigated paddy field, swamp and river beds. \\
\hline 7 & Water body & This category includes reservoir, rivers and pounds. \\
\hline 8 & Bare land & The soil surface cleared and without vegetation. \\
\hline
\end{tabular}

Table 2 shows the description of eight land use classes which set up for land use classification that including Dense Forest (DF), Secondary Forest/mixed forest or Shrub Land (SF/SL), Lowland Agricultural Land (LL), Upland Agricultural Land (UL), Rubber Plantation (RP), Wetland/irrigated Land (WL), Water bodies (W) and Bare Land (BL). In the image processing, four Landsat $5 \mathrm{TM}$ images with different acquisition dates were independently classified with eight land use classes.

\subsection{Classification Accuracy}

A most common and typical method used to assess classification accuracy and overall accuracy is the use of an error matrix or sometimes called a confusion matrix or contingency table (Card, 1982; Congalton, 1991). In this study, we modified and calculated the overall accuracy $(\mathrm{OA})$ as following question:

$$
O A=\left[\left(P_{1}+P_{2}+\ldots . .+P_{n}\right) 100\right] T P
$$

Where, $O A$ is the overall accuracy of each land use classification map, $P$ is the number of joining pixelin the matrix table defied in the rows and columns for category ( 1 to $n$ ). TP is the total pixel of rowsequal columns.

\subsection{Change Detection}

The change detection (CD) provides the trend of changes in land cover and is an important process to monitor and manage natural resources (Mahmoodzadeh, 2007). The change detection matrix is obtained by using pixel by pixel method of two land use maps between 2001/2004; 2004/2007; 2007/2010 and 2001/2010. We use the GIS analysis module of the ERDAS Imagine 9.2 to identify the change detection matrix.

The change detection matrix between different periods is calculated by the following questions:

$$
C D_{i j}=\left[\left(T C_{i}-T C_{j}\right) / T C_{j}\right] 100
$$

Where, $C D_{i j}$ is the change of land use class in columni relative to the previous study compared year, $T C_{i}$ is the total column of areas for category $i$, and $T C_{j}$ is the totalrow of areas for category $j$.

\subsection{Binary Logistic Regression Model}

The primary data collected through structured questionnaires survey were statistically analyzed SPSS version 16.0. Percentages and frequencies ware calculated to explain the statistical characteristics of farmers and input 
variables of land use change. The binary logistic regression model is adopted to analyze socio-economic factors that affected LUC. The LUC is considered as a dependent variable (output) influenced by 8 independent variables (inputs) which include: Family Size $\left(\mathrm{X}_{1}\right)$, Paddy Field $\left(\mathrm{X}_{2}\right)$, Maize Farmland $\left(\mathrm{X}_{3}\right)$, Education Level $\left(\mathrm{X}_{4}\right)$, Upland Rice $\left(\mathrm{X}_{5}\right)$, Rubber Plantation $\left(\mathrm{X}_{6}\right)$, Ethnic Group $\left(\mathrm{X}_{7}\right)$, and Farm Location/Distance $\left(\mathrm{X}_{8}\right)$.

In this study, the logistic regression model was applyied because of its advantages over probit models and mathematical simplicity that give meaningful results (Asrat et al., 2004). The logistic regression equation is based on the principle which uses logarithmic terms to express the multiple linear regression equation. Thus, the problem of violating the assumption of linearity is overcome. It is useful for the effects of continuous, categorical and dummy independent variables on a dichotomous dependent variable (Tiwari et al., 2008). The logistic model can be applied for transferring dependent variables to predict probabilities between 0 and 1 (Sheikh et al., 2003). Besides the utility of the coefficient of variable for testing the usefulness of predictors, odds ratio is easier to interpret and represent the ratio change in the odds of land use change happening for a one-unit change in the predictor (Wahid et al., 2008). Moreover, it can be interpreted as a multiplier of the odds of being land use change or not of the land covers. If the value is greater than 1 , then it indicates that the predictor increases and the odds of land use change increases. Conversely, a value is less than 1, indicating that the predictor decreases and the odds of land use change decreases (Field, 2009).

In this study, the LUC is a dependent variable influenced by independent variables (socio-economic factors). In order to make the qualitative to quantitative variablefor fitting in the regression model, artificial variables with value of 1 or 0 are created, where 1 indicates the presence and 0 is the absence of that attribution (Gujrati, 2003). We assumed that if LUC is equal to 1 , land use changed, while 0 is otherwise or not changed.

To analyze the factors that influencing the land use change, in this study we applied the logistic regression model for the period of 2001 to 2010 by using data set socio-economic data as can be modeled in the equation below:

$$
Y_{i(2001-2010)}=\beta_{0}+\beta_{1} x_{1}+\beta_{2} x_{2}+\beta_{3} x_{3}+\beta_{4} x_{4}+\beta_{5} x_{5}+\beta_{6} x_{6}+\beta_{7} x_{7}+\beta_{8} x_{8}+\mu
$$

Where, $\mathrm{Y}_{\mathrm{i}}=\mathrm{LUC}$ (if $\mathrm{Y}=1$ land use change in the farm at the time period, while $\mathrm{Y}=0$ is otherwise); $\beta_{0}$ is constant; $\beta_{i}(\mathrm{i}=1 \sim \mathrm{n})$ are the estimated model coefficients; $\mathrm{x}_{i}(\mathrm{i}=1 \sim 8)$ are the independent variables and finally $\mu$ is a random error term.

Table 3. Characteristics of independent variables selected for the logistic regression model

\begin{tabular}{|c|c|c|}
\hline Independent Variables & Unit & Variable type \\
\hline Family size $\left(\mathrm{X}_{1}\right)$ & Person & Continuous \\
\hline Paddy Field $\left(\mathrm{X}_{2}\right)$ & Hectare & Continuous \\
\hline Maize Farmland $\left(\mathrm{X}_{3}\right)$ & Hectare & Continuous \\
\hline Education level $\left(\mathrm{X}_{4}\right)$ & Year & Continuous \\
\hline Upland Rice $\left(\mathrm{X}_{5}\right)$ & Dummy & $\begin{array}{l}\text { Dummy, taking a value of } 1 \text { if the farmer practice slash and } \\
\text { burn, and } 0 \text { is otherwise }\end{array}$ \\
\hline Rubber Plantation $\left(\mathrm{X}_{6}\right)$ & Dummy & $\begin{array}{l}\text { Dummy, taking a value of } 1 \text { if the farmer has rubber } \\
\text { plantation, and } 0 \text { is otherwise }\end{array}$ \\
\hline Ethnic group $\left(\mathrm{X}_{7}\right)$ & Dummy & $\begin{array}{l}\text { Dummy, taking a value of } 1 \text { if the plots owner is Khmu } \\
\text { and Hmong people, and } 0 \text { is otherwise }\end{array}$ \\
\hline Road access $\left(\mathrm{X}_{8}\right)$ & Dummy & $\begin{array}{l}\text { Dummy, taking a value of } 1 \text { if the plot's distance less than } \\
500 \mathrm{~m} \text { from the main road, and } 0 \text { is otherwise }\end{array}$ \\
\hline
\end{tabular}

Source: Filed survey 2010-2011.

Table 3 shows the characteristic of the independent variables included in the logistic model. There were eight independent variables (inputs) in the Table 3 were used to analyze the determinant factors of land use change through a binary logistic regression model. 


\section{Results and Discussions}

\subsection{Land Use Change in the Study Area (Spatial Analysis)}

This discussion is based on results of images interpreted and together with observedduring field survey in Nam Tin Watershed. The land use maps generated from the satellite images with aid of field survey were interpreted. The results indicate that the major landscape in the study area is characterized by mixed land covers, especially with secondary forest and shrub land dominant in area.

Table 4. Land use types and areas in hectare of 2001, 2004, 2007 and 2010.

\begin{tabular}{|c|c|c|c|c|c|c|c|c|c|}
\hline \multirow{2}{*}{\multicolumn{2}{|c|}{ No.Land use type }} & \multicolumn{2}{|c|}{2001} & \multicolumn{2}{|c|}{2004} & \multicolumn{2}{|c|}{2007} & \multicolumn{2}{|c|}{2010} \\
\hline & & \multirow{2}{*}{$\frac{\text { ha }}{9,740.9}$} & \multirow{2}{*}{$\begin{array}{c}\% \\
43.9\end{array}$} & \multirow{2}{*}{$\frac{\text { ha }}{4,444.3}$} & \multirow{2}{*}{$\frac{\%}{20.0}$} & \multirow{2}{*}{$\frac{\text { ha }}{5,069.8}$} & \multirow{2}{*}{$\begin{array}{c}\% \\
22.8\end{array}$} & \multirow{2}{*}{$\frac{\text { ha }}{3,021.3}$} & \multirow{2}{*}{$\begin{array}{c}\% \\
13.6\end{array}$} \\
\hline 1 & Dense Forest & & & & & & & & \\
\hline 2 & Secondary forest/ Mixed and shrub land & $7,419.1$ & 33.4 & $9,651.5$ & 43.5 & $8,351.3$ & 37.7 & $9,686.7$ & 43.7 \\
\hline 3 & Lowland agricultural land & $3,079.8$ & 13.9 & $3,168.9$ & 14.3 & $4,052.8$ & 18.3 & $3,808.6$ & 17.2 \\
\hline 4 & Upland agricultural land & $1,854.7$ & 8.4 & $2,465.8$ & 11.1 & $4,003.6$ & 18.0 & $3,204.9$ & 14.4 \\
\hline 5 & Rubber plantation & 0.0 & 0.0 & 0.0 & 0.0 & 233.4 & 1.1 & $1,716.6$ & 7.7 \\
\hline 6 & Wetland/ Irrigated paddy & - & 0.0 & 730.7 & 3.3 & 325.9 & 1.5 & 693.8 & 3.1 \\
\hline 7 & Water body & 55.7 & 0.3 & 116.1 & 0.5 & 58.6 & 0.3 & 68.1 & 0.3 \\
\hline \multirow[t]{2}{*}{8} & Bare land & 49.8 & 0.2 & $1,622.7$ & 7.3 & 104.6 & 0.5 & 0.0 & 0.0 \\
\hline & Total & 22,200 & 100.0 & 22,200 & 100.0 & 22,200 & $100 .($ & 2,200 & 100.0 \\
\hline
\end{tabular}

Overall Accuracy of classification image dated: $2001=76.4 \% ; 2004=80.3 \% ; 2007=85.6 \% ; 2010=89.4 \%$.

Source: Author classified from Landsat 5TM in ERDAS Imagine 9.2 Software.

Table 4 shows the results of land use/land cover classification of the years 2001 to 2010 . The overall accuracy of classification image dated 2010 was $89.4 \%$. It is high compare to other images of 2007, 2004 and 2001 were $85.6 \%, 80.3 \%$ and $76.4 \%$ respectively. The high accuracy of classification image in 2010 due to it was used for the base map of the ground checking. The low accuracy means that there is no ground truth data that belong to images in 2001 to 2007.

Figure 3 shows the results of image interpretation from four Satellite images of 2001, 2004, 2007 and 2010. The upland agricultural area increased from 1854 ha (8\%) to 4003 ha (18\%) from 2001 to 2007 respectively but it decreased to 3204 ha (14\%) in 2010. The increase of upland agricultural area until 2007 was affected by the implementation of agricultural policy. According to Agriculture and Forestry Office of Bokeo Province (PAFO), the main factor behind was a "policy push" aiming at promotion of commercial agriculture such as cash crop production and rubber plantation. Therefore, from 2006 to 2007 both local farmers and investors started occupying the upland fields and fallow forest to grow upland rice, during the first crop season in preparation for rubber plantation after harvesting upland rice as shown in the figure 3-C.

From 2001 to 2004, 2007 and 2010, dense forest has sharply decreased from 9740 ha (44\%), 4444 ha (20\%), 5069 ha (23\%) and 3,021 (13\%) respectively. While secondary forest/mixed or shrub land area has dynamically changed in last 10 years such as has increased from 7419 ha in 2001 to 9651 ha in 2004 and decreased to 8351 in 2007 and has increased to 9686 ha in 2010. Based on the result, in 2010 the dense forest in the study area covered only $13 \%$ of the area and it trends to decrease in the future. This figure (13\%) is too small compared to the national standard of watershed definitions, whichforest cover of $46-60 \%$ of the area (MAF, 2002).

The land use maps of 2007 and 2010 highlight an emerging class of rubber plantation. The area of this class was about 233 ha and 1716 ha, distributed locally especially in the upstream of the watershed area (Figure 3-D). However, during the field survey, we observed that the areas classified as shrub also included rubber plantation. It is because the crown patterns of rubber plantation and shrub forests were similar to each other and sometimes they are mixed with each other. Therefore, we estimated that the actual area of rubber plantation in the study area is greater than 1716 ha. The increase in agricultural areas and secondary forest/mixed or shrub lands are approximately proportional to the decrease ofdense forest areas. Itis possible to explain that the expansion of those land use typesare mostly due to the deforestation, which means some forests were cleared and converted for farming activities in the study area.

The results from the spatial analysis and field survey can be compared by the statistical figure of rubber 
plantation in HouayXaiDistrict. In 2006-2007, the rubber plantation area in HouayXaiDistrict was only 1666 ha which was invested by two Chinese companies. In 2010, the area was rapidly increased to 12137 ha (out of which 1840 ha was planted in the study area) operated by 1164 households in 61 villages, 4 Chinese and 3 Lao investment companies (PAFO, 2011). According to the result of interpreted images and integeted with field survey indicate that a large area of previous paddy fields along the main roads have been converted to banana and watermelon fields. According to the PAFO reports, in 2010 the areas of banana and watermelon were 17 ha and 250 ha respectively and they seem to have high potential to increase year after year.
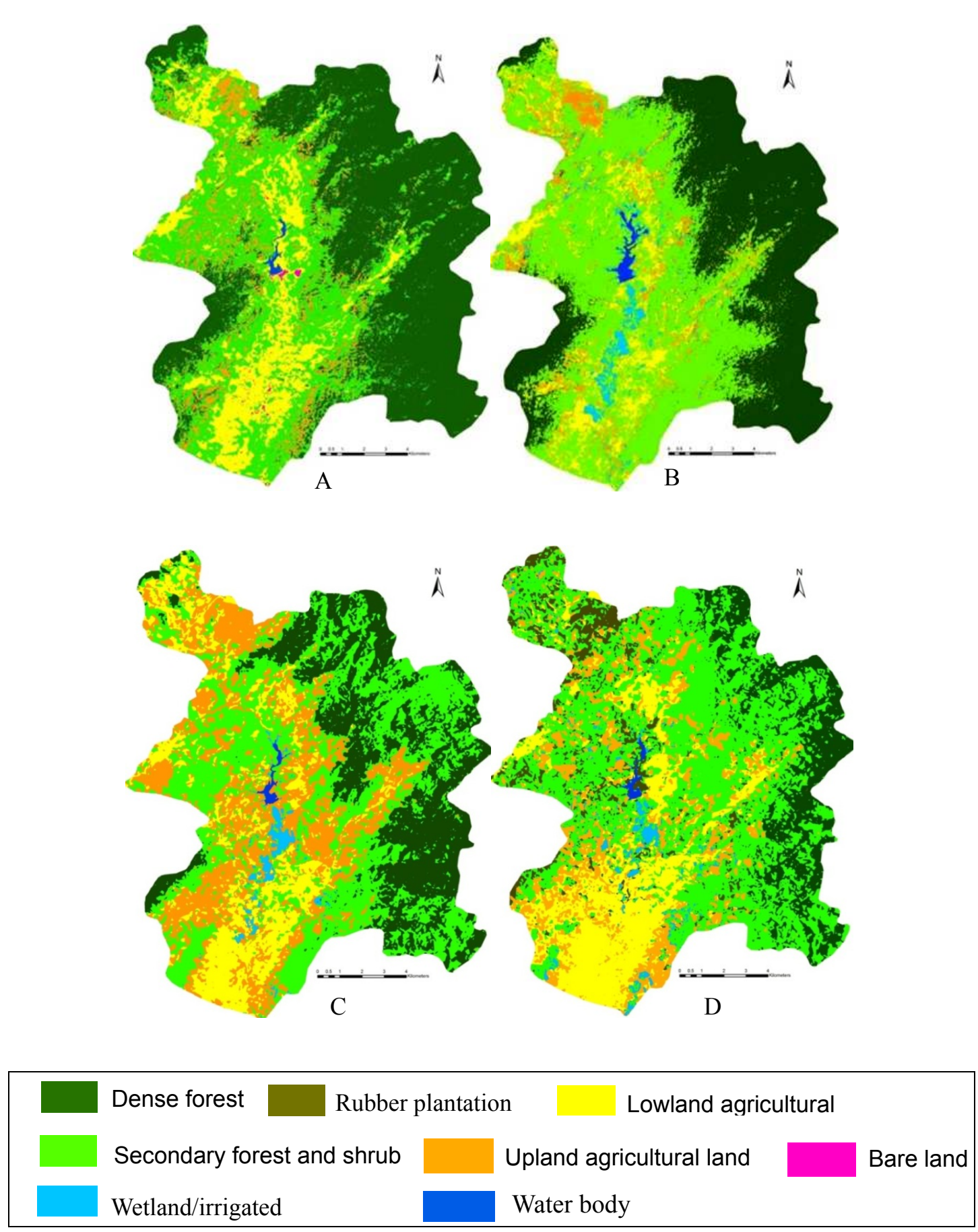

Figure 3. Land Use Maps: A) 2001, B) 2004, C) 2007 and D) 2010

Source: Author Interpreted from Satellite Images by ERDAS Imagine 9.2 Software. 


\subsubsection{Change Detection from 2001 to 2004}

Table 5. Change detection matrix of land use and land cover classes from 2001 to 2004 in hectare

\begin{tabular}{|c|c|c|c|c|c|c|c|c|c|}
\hline \multirow[t]{2}{*}{ Year } & \multicolumn{9}{|c|}{2004} \\
\hline & LUC & DF & $\mathrm{SF} / \mathrm{Sh}$ & LL & UP & $\mathrm{WL} / \mathrm{I}$ & $\mathrm{W}$ & $\mathrm{BL}$ & Total \\
\hline \multirow{8}{*}{2001} & DF & $3,729.8$ & $5,643.2$ & 234.2 & 75.6 & 48.9 & 0 & 96.3 & 9,828 \\
\hline & $\mathrm{SF} / \mathrm{Sh}$ & 339.4 & $3,412.1$ & $1,622.4$ & $1,012.6$ & 351.4 & 29.6 & 694.7 & 7,462 \\
\hline & LL & 17.6 & 331.6 & $1,193.4$ & 370.8 & 317.2 & 47.3 & 790.9 & 3,069 \\
\hline & UP & 80.3 & 354.0 & 150.4 & $1,046.0$ & 0 & 0.4 & 55.4 & 1,687 \\
\hline & $\mathrm{WL} / \mathrm{I}$ & 0 & 0 & 0 & 0 & 0 & 0 & 0 & 0 \\
\hline & W & 0.1 & 2.2 & 56.1 & 0.4 & 5.8 & 38.6 & 1.6 & 105 \\
\hline & $\mathrm{BL}$ & 11.3 & 1.5 & 12.4 & 3.4 & 7.4 & 0.2 & 13.8 & 50 \\
\hline & Total & $4,178.4$ & $9,744.5$ & $3,268.9$ & $2,508.8$ & 730.7 & 116.1 & $1,652.7$ & 22,200 \\
\hline \multicolumn{2}{|c|}{$\begin{array}{r}\text { Change } \\
2001 / 2004 \text { (ha) }\end{array}$} & $-5,649$ & $2,282.4$ & 41.6 & 980.8 & 730.7 & 11.4 & -36.2 & \\
\hline & $(\%)^{*}$ & $-57.5 \%$ & 30.6 & 1.4 & 58.2 & 100 & 10.9 & -72.4 & \\
\hline
\end{tabular}

Note: $\mathrm{DF}=$ Dense forest, $\mathrm{SF} / \mathrm{Sh}=\mathrm{Secondary}$ forest/Shrub land, $\mathrm{LL}=$ Lowland agricultural area, UP=Upland agricultural area, $\mathrm{RP}=$ Rubber plantation, $\mathrm{WL} / \mathrm{I}=$ Wetland/Irrigated paddy, $\mathrm{W}=$ Water body, $\mathrm{BL}=\mathrm{Bare}$ land; * the percentage of change was calculated by formula (2). DF $=[(4,178-9,828) / 9,828] 100=57.5 \%$.

Table 5 shows detail detected changes of land cover in the study area from 2001 to 2004. In 2001, the dense forest and bare land decreased by $57.5 \%$ and $72 \%$ respectively. In contrast, secondary forest/mixed forest or shrub land, upland agriculture and wetland/irrigated areas increased by $30.6 \%, 58.2 \%$ and $100 \%$ respectively, in 2004.

Dense forest changed to agricultural lands includingupland and lowland agricultural by 234.2 ha, 75.6 ha (309.8 ha) respectively. On the other hand, more than 5600 ha of dense forest werechanged to secondary forest/mixed or shrub. Nearly 1600 ha and 1000 ha of secondary forest/mixed or shrub land was converted to lowland and upland agricultural areas respectively, and other 350 ha and 690 hachanged to wetland/irrigated paddy field and bare land respectively. Conversely, agricultural land (lowland and upland) was also changed to other land uses such as secondary forest/mixed or shrub $687 \mathrm{ha}$, and bare land $846 \mathrm{ha}$. The result clearly showed that the main cause of deforestation was expansion of agricultural land and secondary forest/shrub (former of shifting cultivation areas). This change is attributed to the construction of the irrigation project (Southavilay, 2005). After the completion of irrigation dam, large numbers of farmers who lost their farm lands by submergence have returned to practice of shifting cultivation by clearing forests.

\subsubsection{Change Detection from 2004 to 2007}

Table 6 presents the dense forest that has continually decreased in the study area. In 2007, dense forest decreased about 1500 ha (22\%), in contrast to the increased of upland agriculture and rubber plantation by $150 \%$ and $100 \%$, respectively. The increase of agricultural land was due to secondary forest/mixed or shrub land changed to agricultural land by some 1700 ha. More than 1300 ha and 230 ha of bare land changed to agricultural land and secondary forest/mixed or shrub land respectively, while bare land was not classified in 2007. This can be explained by the dynamics of shifting cultivation, which is characterized reversion of land covers between agricultural land and secondary forest/mixed or shrub land. The conversion of agricultural and secondary forest/mixed or shrub land to rubber plantation was initiallystarted in this period with the area of 94 ha and 120 ha respectively. 
Table 6. Change detection matrix of land use/land cover classes from 2004 to 2007 in hectare

\begin{tabular}{|c|c|c|c|c|c|c|c|c|c|c|}
\hline \multicolumn{6}{|l|}{ Year } & \multicolumn{5}{|c|}{007} \\
\hline \multirow{10}{*}{2004} & LUC & $\mathrm{DF}$ & $\mathrm{SF} / \mathrm{Sh}$ & LL & Up & $\mathrm{RP}$ & WL/I & W & $\mathrm{BL}$ & Total \\
\hline & $\mathrm{DF}$ & 2398.3 & 3834.7 & 111.7 & 185.1 & 3.4 & 0.3 & 0.0 & 0 & 6,534 \\
\hline & $\mathrm{SF} / \mathrm{Sh}$ & 2629.1 & 3913.9 & 207.3 & 1502.2 & 120.5 & 82.4 & 0.0 & 0 & 8,456 \\
\hline & LL & 6.2 & 738.9 & 1427.1 & 903.7 & 64.4 & 43.1 & 0.0 & 0 & 3,183 \\
\hline & UP & 1.3 & 287.5 & 420.4 & 880.1 & 7.2 & 3.8 & 0.0 & 0 & 1,600 \\
\hline & $\mathrm{RP}$ & 0 & 0 & 0 & 0 & 0 & 0 & 0 & 0 & 00 \\
\hline & WL/I & 9.8 & 210.1 & 80.9 & 185.9 & 23.1 & 168.3 & 2.44 & 0 & 681 \\
\hline & W & 0.0 & 4.3 & 33.6 & 1.2 & 1.8 & 18.9 & 56.1 & 0 & 116 \\
\hline & BL & 1.3 & 232.3 & 1035.4 & 339.2 & 12.9 & 9.1 & 0.0 & $\mathbf{0}$ & 1,630 \\
\hline & Total & 5045.9 & 9221.9 & 3316.4 & 3997.5 & 233.4 & 325.9 & 58.5 & 0 & 22,200 \\
\hline \multicolumn{2}{|c|}{$\begin{array}{r}\text { Change } \\
2004 / 2007 \text { (ha) }\end{array}$} & -1487 & 766.3 & 133.1 & 2397.2 & 233.4 & -354.7 & -57.5 & -1630 & \\
\hline & $\%$ & -22.8 & 9.1 & 4.2 & 149.8 & 100.0 & -52.1 & -49.5 & -100 & \\
\hline
\end{tabular}

Note: $\mathrm{DF}=$ Dense forest, $\mathrm{SF} / \mathrm{Sh}=$ Secondary forest/Shrub land, $\mathrm{LL}=$ Lowland agricultural area, UP=Upland agricultural area, $\mathrm{RP}=$ Rubber plantation, $\mathrm{WL} / \mathrm{I}=\mathrm{Wetland} /$ Irrigated paddy, $\mathrm{W}=\mathrm{W}$ ater body, $\mathrm{BL}=\mathrm{Bare}$ land

5.1.3 Change Detection from 2007 to 2010

Table 7. Change detection matrix of land use and land cover classes from 2007 to 2010 in hectare

\begin{tabular}{|c|c|c|c|c|c|c|c|c|c|}
\hline \multirow[t]{2}{*}{ Year } & \multicolumn{9}{|c|}{2010} \\
\hline & LUC & DF & $\mathrm{SF} / \mathrm{Sh}$ & LL & $\mathrm{Up}$ & $\mathrm{RP}$ & $\mathrm{WL} / \mathrm{I}$ & $\mathrm{W}$ & Total \\
\hline \multirow{8}{*}{2007} & $\mathrm{DF}$ & 2055.4 & 2508.4 & 40.3 & 287.9 & 154.0 & 23.9 & 0.0 & 5,070 \\
\hline & $\mathrm{SF} / \mathrm{Sh}$ & 959.0 & 4658.8 & 620.4 & 1199.9 & 628.5 & 283.6 & 1.2 & 8,351 \\
\hline & LL & 0.6 & 887.3 & 2170.8 & 583.5 & 299.1 & 200.2 & 16.3 & 4,158 \\
\hline & UP & 6.2 & 1511.1 & 920.9 & 877.4 & 544.7 & 141.8 & 1.6 & 4,004 \\
\hline & $\mathrm{RP}$ & 0.2 & 111.0 & 14.1 & 29.9 & 69.6 & 8.1 & 0.3 & 233 \\
\hline & WL/I & 0.0 & 92.5 & 41.0 & 45.8 & 19.4 & 124.1 & 3.1 & 326 \\
\hline & W & 0.0 & 1.6 & 1.2 & 0.6 & 1.3 & 8.1 & 45.7 & 59 \\
\hline & Total & 3021.3 & 9770.7 & 3808.6 & 3024.9 & 1716.6 & 789.8 & 68.1 & 22,200 \\
\hline & $\begin{array}{r}\text { Change in } \\
2007 / 2010 \text { (ha) }\end{array}$ & $-2,048.5$ & $1,419.4$ & -349.1 & -978.6 & $1,483.4$ & 463.9 & 9.50 & \\
\hline & $\%$ & -40.4 & 17.0 & -8.4 & -24.4 & 37.1 & 142.4 & 16.2 & \\
\hline
\end{tabular}

Note: $\mathrm{DF}=$ Dense forest, $\mathrm{SF} / \mathrm{Sh}=$ Secondary forest/Shrub land, $\mathrm{LL}=$ Lowland agricultural area, UP=Upland agricultural area, $\mathrm{RP}=$ Rubber plantation, $\mathrm{WL} / \mathrm{I}=$ Wetland/Irrigated paddy, $\mathrm{W}=$ Water body, $\mathrm{BL}=\mathrm{Bare}$ land.

Table 7 indicates the change detection matrix of land use and land cover from 2007 to 2010. In this period, agricultural lands changed to secondary forest/mixed or shrub land by nearly 2400 ha. While the latter one changed to the former by 2800 ha, which seems general balanced with each other. For the dense forest, lowland and upland agriculture reduced by $40 \%, 8 \%$ and $24 \%$, respectively. 
The rubber plantation area was rapidly increased in this period by $37 \%$, mostly converted from agricultural, secondary forest/mixed or shrub land and even dense forest by 860 ha, 629 ha and 154 ha respectively. Since 2006, when rubber plantation was firstly introduced to Bokeo province in the form of land concession and contract farming by Chinese companies, the area of rubber plantation in the province has been rapidly increased from 55 ha in 2006 to 24,100 ha in 2010 . This figure did not include private or smallholder rubber plantation. In 2011, there were 9 Chinese investment companies and 3 Lao investment companies operating rubber plantations in Bokeo province (PAFO, 2011). This indicates that the land use and farmers' livelihood in northern Laos are rapidly changingfrom subsistence to market oriented agricultural system, following after the changes of socio-economic development policies.

\subsubsection{Change Detection from 2001 to 2010}

Table 8. Change detection matrix of land use and land cover classes from 2001 to 2010 in hectare

\begin{tabular}{llccccccccc}
\hline Year & \multicolumn{10}{c}{2010} \\
\hline & LUC & DF & SF/Sh & LL & Up & RP & WL/I & W & BL & Total \\
\cline { 2 - 10 } & DF & $\mathbf{2 , 8 7 4 . 3}$ & $5,388.1$ & 218.5 & 797.7 & 415.1 & 135.1 & 0.0 & 0.0 & 9,829 \\
& SF/Sh & 104.0 & $\mathbf{2 , 9 0 8 . 3}$ & $1,772.3$ & $1,567.4$ & 791.1 & 319.3 & 15.3 & 0.0 & 7,478 \\
& LL & 1.8 & 667.6 & $\mathbf{1 , 6 3 0 . 4}$ & 351.8 & 255.4 & 152.3 & 90.6 & 0.0 & 3,150 \\
& UP & 24.1 & 768.9 & 167.2 & $\mathbf{3 4 7 . 4}$ & 235.0 & 77.1 & 0.1 & 0.0 & 1,620 \\
& RP & 0.0 & 0.0 & 0.0 & 0.0 & $\mathbf{0 . 0}$ & 0.0 & 0.0 & 0.0 & 0 \\
& WL/I & 0.0 & 0.0 & 0.0 & 0.0 & 0.0 & $\mathbf{0 . 0}$ & 0.0 & 0.0 & 0 \\
& W & 0.0 & 8.4 & 19.8 & 1.4 & 5.9 & 5.3 & $\mathbf{3 1 . 9}$ & 0.0 & 73 \\
& BL & 0.0 & 9.2 & 26.3 & 8.3 & 2.9 & 3.9 & 0.2 & $\mathbf{0 . 0}$ & 51 \\
& Total & $3,004.2$ & $9,750.6$ & $3,834.5$ & $3,074.0$ & $1,705.4$ & 692.9 & 138.1 & 0.0 & 22,200 \\
\hline Change in & $-6,824.5$ & $2,272.8$ & 684.7 & $1,454.3$ & $1,705.4$ & 692.9 & 65.4 & -51 &
\end{tabular}

Note: $\mathrm{DF}=$ Dense forest, $\mathrm{SF} / \mathrm{Sh}=\mathrm{Secondary}$ forest/Shrub land, $\mathrm{LL}=$ Lowland agricultural area, UP=Upland agricultural area, $\mathrm{RP}=$ Rubber plantation, $\mathrm{WL} / \mathrm{I}=$ Wetland/Irrigated paddy, $\mathrm{W}=$ Water body, $\mathrm{BL}=$ Bare land .

Table 8 shows the land use/land cover has sharply changed over the period from 2001 to 2010 in the study area. During the past 10 years, dense forest decreased about $70 \%$ by conversion to secondary forest/mixed or shrub on a large scale (5388 ha) as well as to upland and lowland agricultural areas by 798 ha and 219 ha respectively. The contrary conversions were only about $104 \mathrm{ha}, 24 \mathrm{ha}$ and $1 \mathrm{ha}$. On the other hand, the converted areas from secondary forest/shrub to lowland and upland agricultural amounted to 1772 ha and 1567 ha respectively. In contrast, the changed areas of lowland and upland agricultural areas to secondary forest/shrub accounted for 769 ha and 668 ha respectively. This can be interpreted as the conversion of former upland rice areas to fallow forest and secondary forest.

The area of rubber plantation in 2010 had been converted mainly from secondary forest/shrub (791 ha) and dense forest (415 ha) followed by lowland agricultural area ( $255 \mathrm{ha})$ and upland agricultural area (235 ha). However, it was difficult to estimate the accurate area of change from dense forest to rubber plantation because there was a similarity of spectral characteristics between these two classes. These changes explain the deforestation and change in land use system in the study area. The farmers have expanded newly reclaimed farmland by occupying forests and also converted their existing farmlands to rubber plantation and upland rice. We concluded that these changes were caused by government policy, aimingpromotes income generation through the commercial agricultural production.

Another remarkable change in the study area was an expansion of lowland agricultural area, on which farmers' needs were reflected to increase products, especially maize, in order to meet the demand of market whilethe it production has low productivity. According to Southavilay et al 2010, studied on productive efficiency of maize farmers in this area found that the average yield ranged from 1.5 to $2.8 \mathrm{t} / \mathrm{ha}$ for upland maize farmers. It was low 
comparedtoaverage yield atnational level $(4.7 \mathrm{t} / \mathrm{ha})$. Their study concluded that the low yield of maize production maybe due to farmers have low technical efficiency (low farms' skill), especially upland maize farmers who operate their farm at a lower level of technical efficiency than lowland maize farmers of $41 \%$ and $76 \%$ respectively. Therefore, increased yield and productivity are difficult for northern farmers. Consequently, forest land is one of the most practical options for farmers to expand their cultivated land under such condition. The farmers in this area already depended on such commercial agricultural crops as maize and banana as well as industrial tree crop as rubber. This has caused a decrease in forest area, especially in the eastern and northern parts of watershed areas in an uncontrolled manner.

\subsection{Regression Analysis}

Table 9. Summary of the socio-economic characteristic of the independent variables

\begin{tabular}{lcccccc}
\hline \multicolumn{1}{c}{ Independent Variables } & Category & Ratio $(\%)$ & Mean & $\begin{array}{c}\text { Standard } \\
\text { Deviation }\end{array}$ & Max & Min. \\
\hline Family size $\left(\mathrm{X}_{1}\right)$ & - & - & 4.92 & 1.45 & 9.00 & 3.00 \\
Paddy Field $\left(\mathrm{X}_{2}\right)$ & - & - & 1.10 & 0.79 & 5.00 & 0.00 \\
Maize Farmland $\left(\mathrm{X}_{3}\right)$ & - & - & 1.57 & 0.99 & 6.00 & 0.32 \\
Education level $\left(\mathrm{X}_{4}\right)$ & Illiterate & 10.0 & - & - & - & - \\
& Primary & 58.2 & - & - & - & - \\
& Secondary & 19.4 & - & - & - & - \\
& College & 9.20 & - & - & - & - \\
& University & 3.10 & - & - & - & - \\
Upland Rice $\left(\mathrm{X}_{5}\right)$ & Practice & 41.33 & - & - & - & - \\
& No & 58.67 & - & - & - & - \\
Rubber Plantation $\left(\mathrm{X}_{6}\right)$ & Practice & 36.00 & - & - & - & - \\
Ethnic group $\left(\mathrm{X}_{7}\right)$ & No & 64.00 & - & - & - & - \\
Distance $\left(\mathrm{X}_{8}\right)$ & Khmu Hmong & 48.00 & - & - & - & - \\
& No & 52.00 & - & - & - & - \\
& $<500 \mathrm{~m}$ & 57.33 & - & - & - & - \\
\hline
\end{tabular}

Source: Survey data, 2010-2011.

Table 9 shows the major socio-economic characteristics of the sample farmers in the study area. The majority of sample farmers $(58.2 \%)$ completed primary school, followed by secondary school (10.4\%), and college (9.2\%). Only $3.1 \%$ of the sample farmers had completeduniversity degree, while $10 \%$ of them were illiterate. The average of family size, paddy field and maize farm land were 4.92 persons, 1.10 ha and 1.57 ha respectively. The percentage of sample farmers forupland rice and rubber was $41.33 \%$ and $36 \%$ respectively, and $48 \%$ of sample farmersare Khmu and Hmong people. $57.33 \%$ of GPS record points are located within 500 meters along the main roads.

Table 10. Parameter estimates for the significant variables in the logistic regression model (2001-2010)

\begin{tabular}{|c|c|c|c|c|c|c|c|}
\hline \multirow{2}{*}{ Independent Variables } & \multirow{2}{*}{ B } & \multirow{2}{*}{ S.E. } & \multirow{2}{*}{ Wald } & \multirow{2}{*}{ Sig. } & \multirow{2}{*}{$\operatorname{Exp}(B)$} & \multicolumn{2}{|c|}{$95.0 \%$ C.I.for EXP(B) } \\
\hline & & & & & & Lower & Upper \\
\hline Family size $\left(\mathrm{X}_{1}\right)$ & .366 & .441 & .687 & .407 & 1.441 & .607 & 3.421 \\
\hline Paddy Field $\left(X_{2}\right)$ & 164 & .568 & .083 & .773 & 1.178 & 387 & 3.588 \\
\hline Maize Farmland $\left(\mathrm{X}_{3}\right)$ & $.460^{* *}$ & .440 & 1.092 & .029 & .631 & .266 & 1.496 \\
\hline Education level $\left(\mathrm{X}_{4}\right)$ & $-.411 *$ & 248 & 2.744 & .098 & .663 & 408 & 1.078 \\
\hline Upland Rice $\left(\mathrm{X}_{5}\right)$ & $1.021^{* *}$ & 1.044 & .956 & .028 & 2.775 & 359 & 21.464 \\
\hline Rubber Plantation $\left(\mathrm{X}_{6}\right)$ & $2.207 * *$ & .996 & 4.912 & .027 & 9.090 & 1.291 & 64.005 \\
\hline Ethnic group $\left(X_{7}\right)$ & $3.741^{* * *}$ & 1.281 & 8.534 & .003 & 42.131 & 3.425 & 518.313 \\
\hline Farm distance $\left(\mathrm{X}_{8}\right)$ & $2.422^{* * *}$ & 1.180 & 4.216 & .000 & 11.272 & 1.116 & 113.806 \\
\hline Constant & $-2.358^{* *}$ & 1.250 & .697 & .040 & .041 & & \\
\hline
\end{tabular}


Notes: *, **, *** Significant at $10 \%(\mathrm{P}<0.1), 5 \%(\mathrm{P}<0.05)$ and $1 \%(\mathrm{P}<0.01)$ confidence, respectively; -2 Likelihood $=38.395 ;$ Chi-square $=57.212 ;$ Cox and Snell $R^{2}=0.558 ;$ Nagelderke $R^{2}=0.750$.

\section{Source: Result of Binary Analysis from SPSS16.0}

Table 10 shows the results of binary logistic regression analysis as described in the model (equation 3 ). In the models, eight independent variables were analyzed using binary logistic regression to examine their relation with land use changes. The overall measure of fitness of the model is given by the likelihood value $(-2 \log$ Likelihood). $-2 \log$ Likelihood provides how well the model fits to the data. In this study, -2 log Likelihood value was 38.395 , and indicated that the data fits to the model because a well-fitting model will have a small value for $-2 \log$ Likelihood (Hair et al., 1998). The smaller value the better indicates fitness.

In this analysis, the probability of the model chi-square (57.212 and Sig .000) was less than the level of significance at 0.05 . The null hypothesis has no difference between the model with only a constant and the model with independent variables which was rejected. This indicated that the existence of a relationship between the independent variables and the dependent variable was supported. The fitness of the model was also determined by the Coxand Snell $\left(\mathrm{R}^{2}=0.588\right)$ and the Nagelkerke $\left(\mathrm{R}^{2}=0.750\right)$ methods. The Nagelkerke value can be explained that $75 \%$ of land use changes havea relationship with the independent variables in the model and the overall accuracy rate was computed by SPSS with $87.1 \%$. This implied that characteristic of this model appreciated for the analysis. Six of eight independent variables havestatistical significance to the land use changes. The null hypothesis of B coefficient for the six independent variables was equal to zero and was rejected.The relationship between each independent variab leand dependent variable will be discussed as follows:

The maize farmland variable has a positive significant relationship with land use change at $5 \%$ level. The model shows that a unit of maize farmland increased will lead to increase the odds of land use change by a factor of 0.631 . This significance also supported to the result of spatial analysis. It revealed that lowland agricultural area which contained the maize farmland in 2010 was mainly converted fromsecondary forest/mixed or shrub land and lowland agricultural area. The harvested area of maize in the study area was rapidly increased from 6500 to 21800 ha in fiscal years of 2005 and 2008 respectively, and decreased to 19,000 ha in 2010. The decrease of maize production in 2010 was because some of maize farmland changed to rubber plantation (Southavilay et al., 2011).

The upland rice variable had a positive significant relationship with land use change at $5 \%$ level. The model shows that a unit of upland rice increases will lead to raise the odds of land use change by a factor of 2.775. This significance clearly supports the result of land use maps. The upland agricultural area (included upland rice) had dynamic changed in 2001, 2004, 2007 and 2010. The upland rice field is a kind of temporary land use type and itis oftenconverted to other land use's purposes. As it can be seen from the change detection technique are mainly upland rice field changed to secondary forest/mixed or shrub land and rubber plantation. Based on field observation, the upland rice field scattered throughout the study area, especially along the both sides of east and west within watershed area. According to the statistical data of district of Agriculture and Forestry Office (DAFO) shows that farmers who have been practicing upland rice are mostly Khmu and Hmong people, and those farmers have limited lowland agricultural area (paddy field) and lack of financial support to invest commercial agricultural production activities.

The probability of the Wald statistic for the variable of education level was negatively significant at $10 \%$ level. The value of Exp (B) was 0.663 which implies that a unit increased in education level of sample farmers respondents will lead to decrease the odds (probability) ofland use change by a factor of 0.663 . It indicates that educated farmers do not regularly change their farmlands. According to spatial analysis from 2001 to 2010 found that the pixels of paddy field that included in the lowland agricultural class were not changed. From the field checked, According to the field checked, those types of land uses belong to educated farmersare not converted to other activity uses. On the other hand, educated farmersdo not only have agricultural activities for their livelihoodandalso run other businesses such as trading and non-farm activities.

The rubber plantation variable had a positive significant relationship with land use change at $1 \%$ level. The model shows that a unit of rubber plantation increases will lead to raise the odds of land use change by a factor of 9.907. It means that the rubber plantation had a high potential impact on agricultural land and forest covers. This result supports the spatial analysis of land use mapin 2010. The rubber plantation was largely planted throughout the study area (1700 ha or $8 \%$ of total area). In addition, this finding agrees with the work of Thongmanivong et al (2010) who studied the impacts of recent rubber investment on land tenure and livelihoods 
in northern Laos. Their study found that the impact of rubber plantation was not only on agricultural land and livelihood but it also had negative impacts on the forest covers.

The variable onethnic grouphad a positive significant relationship with land use change at $5 \%$ level. The model shows that a unit of ethnic group increased will lead to raise the odds of land use change by a factor of 42.131 . The odds ratio was the highest variable among six variables included in the model. It implies that this variable has high probability of land use change. It can be agreed that the main activities of Khmu and Hmong farmersare usually relied on shifting cultivation and non-permanent farmland activities. Therefore, this group easily changed their farmland and convertedforest nearby the villagesto other uses. According to the image classification and field observation revealed that the land use and land cover around their villages were totally changed during the past 10 years. The majority of change was fromdense forest to upland agricultural land (upland rice), and upland agricultural land to rubber plantation. This finding agrees with the work of Thongmanivong and Fujita (2009) studied of agrarian land use transformation in northern Laos. Theyfound that Hmong and Akha people were the first group are able to convert areas of swidden and fallow land into a rubber field. Similarly, another variable is farm location that had significant positive relations with land use change.

The variable onfarm locationhad a positive significance associated with land use change at $1 \%$ level. The model shows that the odds of land use changeincreased by a factor of 11.272 of a unit increased in farm location. The possible explanation is that the farmland area was located within 500metersalong the main roads hadhigher probability of land use change than other areas. This finding had the same result with Manivong et al. (2008) who studied economics of smallholder rubber expansion in Northern Laos. Their study found that agricultural land with good accessibility is located along or very close to the main road which easily changed to rubber plantation because rubber can be collected directly from this zone.

\section{Conclusions and Policy Implications}

This study aims to investigate land use and land cover changes and its determinant factors occurred in Nam Tin Watershed in the HouayXay district, Bokeo Province, Laos. GIS, remote sensing and socio-economic were applied to analyzeland use and land cover changes of four time series for the years 2001, 2004, 2007 and 2010 by using Landsat 5TM satellite images. Logistic Regression Model was also applied to analyze the determinant factors contributing land use changes.

The most remarkable change observed in the time period of 2001, 2004, 2007 and2010 was the dynamic decrease of dense forest area from approximately 9700 ha, 4500 ha, 5000 ha and 3000 ha respectively, accounting for $70 \%$ decreased for 10 years. In contrast, the secondary forest/mixed or shrub land was slightly increased between 2001 and 2010. The dense forest cover change was caused mainly by increase of secondary forest/mixed or shrub land and upland agriculture class by $30 \%$ and $90 \%$ respectively.

Since the commercial agricultural production policy had been implemented.Agricultural land (upland and lowland) andrubber plantation areas were rapidly increased in the upstream and along the foothill of the watershed area in an uncontrolled manner. The area of rubber plantations in 2010 was 1700 ha, mostly converted from dense forest (415.06 ha), secondary forest/mixed or shrub land (619.94 ha) and followed by lowland agricultural area (255.38 ha) and upland agricultural area ( $235 \mathrm{ha})$.

The regression analysis model also provides the important policy implication for natural resources management and land use planning. The results show that $75 \%$ of land use change from 2001 to 2010 in the study area is related with the socio-economic factors (independent variables). For this period, there werefiveindependent variables whichaffected on land use change includingupland agricultural land (rice field), rubber plantation, ethnicity (Khmu and Hmong), maize farmland and farm location. The independence variable of education level and paddy field were required for against land use change.

Considering these results, it is urgent to be introducedland use planninginto the study site, especially with respect to the land located within 500 meters along the main roads, because such land has higher probability of conversion. On the other hand, it is also necessary to involveand encourage Khmu and Hmong people to adopt more productive and permanent farmingpracticesinstead of shifting cultivation to prevent forest degradation. Accordingly, we concluded that there is a need to control the pattern of land use change and devise appropriate land use types or cropping pattern for sustainable utilization of land and natural resources in the watershed area. A particularly, in the upstream area where it is urgently necessary to increase forest covers and to control the area of upland rice and rubber plantation for sustainable use of water resources within the watershed area.

Furthermore, widespread conversion of land use such as from swidden and fallow forest into rubber plantation and other mono-cultural patterns will effecton the farmers who have limited agricultural land and low 
education.It means that they may face with limited livelihood option andstarted to lose an access to land and resources. In addition, to control land use change, it needs to improve the cash crop productivityand technical efficiency instead of increasing farm size.

The advantage of this study wasan application of both spatial and socio-economic analysis techniques to identify the change in land use and its determinanton plot or farm scale. The result of this study is useful to understand the situationof land use change and its determinant factors of each time period. The findings of this study will be useful in making policy decision related to land management to improve the existing constraints, especially improvement ofnatural resource management and land use planning in the study area and elsewhere. However, there were also some difficulties that the patterns of land use classes are smaller than pixel size of satellite image ( $25 \times 25$ meters), scattering among one another. It was also difficult to collect socio-economic data for each period of land use change. These problems can be addressed by further study with deep interviews and by applying high resolution of satellite images.

\section{References}

Campbell, J. B. (2007). Introduction to Remote Sensing (4th edition). New York, USA: The Guilford Press.

Congalton, R. G., \& Green, K. (1999). Assessing the accuracy of remotely sensed data: principles and practices. New York: Lewis Publishers.

DAFO (District of Agriculture and Forestry Office) of HouyXay District. (2011). Agricultural Statistic. Bokeo Province, Laos

Demers, M. N. (2005). Fundamental of Geographic Information System. New York, USA: John Wilay \& Sons, Inc..

Field, A. (2009). Discovering statistics using SPSS. England: Sage Publications LTD.

Fox, J., Vogler, J. (2005). Land use and land cover change in mainland Southeast Asia. Environmental Management, 35(5), 1-10.

Gujrati, D. N. (2003). Basic econometrics (4th ed). New York: McGraw Hill.

Phanvilay, K., Thongmanivong, S. (2006). Agrarian land use transformation in upland areas of Northern Laos. SSLWM workshop

Kummer, D. M., \& Turner, B. L. (2007). The Human Causes of Deforestation in Southeast Asia. Bioscience, 44(5), 323-328. http://dx.doi.org/10.2307/1312382

MAF (Ministry of Agriculture and Forestry). (2002). Strategic Vision on Integrated Watershed Management Approach for Sustainable Upland Development and Poverty Alleviation in Laos.

MAF (Ministry of Agriculture and Forestry). (2011). Annual Statistic Report. Vientiane, Laos.

Mahmoodzadeh, H. (2007). Digital Change Detection Using Remotely Sensed for Data Morning Green Space Destruction in Tabriz. International Journal of Environmental Research, 1(1), 35-41.

Manivong, V., \& Cramb, R. A. (2008). Economics of Smallholder Rubber Expansion in Northern Laos. Agroforest System, 74, 113-125. http://dx.doi.org/10.1007/s10457-008-9136-3

PAFO (Provincial of Agriculture and Forestry Office) of Bokeo Province. (2011). Annual Agricultural Statistic Report, Laos.

PIPO (Provincial of Investment and Planning Office) of Bokeo province. (2011). Annual Socio-Economic Report, Laos.

Rogana, J., \& Chen, D. (2004). Remote Sensing technology for mapping and monitoring land-cover and land use change. Progress in Planning, 61, 301-325. http://dx.doi.org/10.1016/S0305-9006(03)00066-7

Selcuk, R. (2008). Analyzing land use and land cover change using remote sensing and GIS in Rize, North-East Turkey. Sensors, 8, 6188-6202. http://dx.doi.org/10.3390/s8106188

Sheikh, A. D., Rehman, T., \& Yates, T. (2003). Logit models for identifying the factors that influence the uptake of new 'no-tillage' technologies by farmers in the rice-wheat and cotton-wheat farming systems of Pakistan`s Punjab. Agricultural System, 75, 79-95. http://dx.doi.org/10.1016/S0308-521X(02)00014-8

Southavilay, B., Nanseki, T., \& Takeuch, S. (2011). Study of farmers' perception and socio-economic determinants on land degradation in northern Laos: a case study of maize production. European Journal of Social-Sciences, 28(4), 502-511. 
Southavilay B. (2005). Development-Induced Displacement and Spatiality of Sustainable livelihoods: A Case Study of The Irrigation Project in Nam Tin Watershed, Houyxai District, Bokeo Province, Laos (pp. 126-128). Master Thesis, Graduate School of Chiang Mai University.

Thongmanivong, S., Yahoi, F., Phanvilay, K., \& Vongvisouk, T. (2009). Agrarian Land use Transformation in Northern Laos: From Swidden to Rubber. Southeast Asia Studies, 47(3), 330-346 